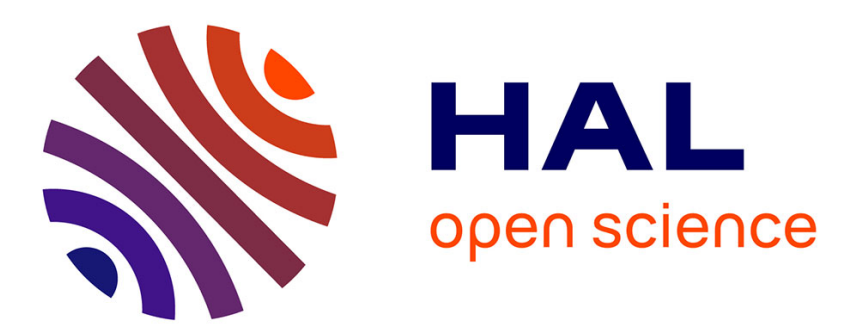

\title{
SrSnO3:N - nitridation and evaluation of photocatalytic activity
}

Tatiane Martins Lobo, Ronan Lebullenger, Valérie Bouquet, Maryline Guilloux-Viry, Ieda Maria Garcia Santos, Ingrid Távora Weber

\section{- To cite this version:}

Tatiane Martins Lobo, Ronan Lebullenger, Valérie Bouquet, Maryline Guilloux-Viry, Ieda Maria Garcia Santos, et al.. SrSnO3:N - nitridation and evaluation of photocatalytic activity. Journal of Alloys and Compounds, 2015, 649, pp.491-494. 10.1016/j.jallcom.2015.05.203 . hal-01169299

\section{HAL Id: hal-01169299 \\ https://hal-univ-rennes1.archives-ouvertes.fr/hal-01169299}

Submitted on 19 Nov 2015

HAL is a multi-disciplinary open access archive for the deposit and dissemination of scientific research documents, whether they are published or not. The documents may come from teaching and research institutions in France or abroad, or from public or private research centers.
L'archive ouverte pluridisciplinaire HAL, est destinée au dépôt et à la diffusion de documents scientifiques de niveau recherche, publiés ou non, émanant des établissements d'enseignement et de recherche français ou étrangers, des laboratoires publics ou privés. 


\section{ACCEPTED MANUSCRIPT}

\section{$\mathrm{SrSnO}_{3}: \mathrm{N}-$ nitridation and evaluation of photocatalytic activity}

Tatiane Martins Lobo $^{\mathrm{a}, \mathrm{b}}$, Ronan Lebullenger ${ }^{\mathrm{b}}$, Valerie Bouquet ${ }^{\mathrm{b}}$, Maryline Guilloux-Viy ${ }^{\mathrm{b}}$, leda Maria Garcia Santos ${ }^{c}$, Ingrid Távora Weber ${ }^{\mathrm{a}, \mathrm{d}}$.

a Instituto de Química, Universidade de Brasília-UnB, Brasília-DF, Brazil

${ }^{b}$ Institut des Sciences Chimiques de Rennes, ISCR, UMR6226 CNRS - Université de Rennes 1, Campus de Beaulieu, 35042 Rennes Cedex, France

'LACOM, Dep. de Química, Universidade de Federal da Paraíba-UFPB, Campus I, João Pessoa-PB, Brazil ${ }^{d} P G M T R$, Universidade Federal de Pernambuco - UFPE, Recife - PE, Brazil

\section{ABSTRACT}

The $\mathrm{SrSnO}_{3}$ was prepared in powders form by a conventional method of solid state reaction and submitted to thermal treatment under $\mathrm{NH}_{3}$ in order to obtain the oxynitride and then promote photocatalytic activity at the visible region. Three different nitridation conditions were tested. The results showed that when the $\mathrm{SrSnO}_{3}$ is subjected to nitridation at moderate conditions $\left(600{ }^{\circ} \mathrm{C}\right.$ and $\left.650{ }^{\circ} \mathrm{C}\right)$ oxynitide is formed preserving the perovskite structure. On the other hand, when the nitridation occurs at more severe conditions $\left(750^{\circ} \mathrm{C}\right)$, it is possible to observe the decomposition of the structure instead of the incorporation of $\mathrm{N}$. Samples in which oxynitride is formed, $\mathrm{SrSnO}_{3}: \mathrm{N}$, showed high potential photocatalysis under visible light, showing to be about 4 times more active than $\mathrm{SrSnO}_{3}$ or $\mathrm{TiO}_{2}$ at the same conditions.

Keywords: Strontium stannate, Oxynitride, Nitridation, Visible range, Photocatalysis, Methylene Blue.

Corresponding Author: Ingrid@ufpe.br or itweber@unb.br 


\section{Introduction}

Recently, perovskites photocatalyst have attracted wild attention in all kinds of photocatalytic applications [1-3]. $\mathrm{SrSnO}_{3}$ is a distorted perovskite with an orthorhombic structure (space group Pbnm) due to tilted octahedra [4]. It has been extensively studied due to its potential as thermally stable capacitors, high-quality humidity sensors and photoluminescent and photocatalytic materials [5-8]. More recently, photocatalytic properties of $\mathrm{SrSnO}_{3}$ have been reported indicating that it is a promising photocatalyst due to its suitable valence band and conduction band edge positions [9-12]. For instance, chemically prepared $\mathrm{SrSnO}_{3}$ nanostructures showed high activity for water splitting $[13,14]$ and methylene blue discoloration $[12,15]$. Nevertheless, the band gap is too large to be used with solar radiation $4,1 \mathrm{eV}[13])$.

Nitridation is a well known strategy to shorten oxide's band gap $[16,17]$. Comparing to metal doping, it presents the advantages of being superficial (not bulk) and disfavors fast electron-hole recombination [18]. For nitrided materials, band gap reduction can be explained by a decrease in electronegativity (3.50 for oxygen and 3.07 for nitrogen) which results in a higher degree of covalency in the metal-anion bonding [19]. Moreover, there is an overlap between $\mathrm{N}_{2 p}$ and $\mathrm{O}_{2 p}$ orbitals which increases the valence band maximum (VBM) $[13,20,21]$.

The literature provides some examples in which $\mathrm{N}$ incorporation resulted in higher photocatalytic activity in the visible region. For instance, $\mathrm{TiO}_{x} \mathrm{~N}_{y}$ [16], $\mathrm{TaO}_{x} \mathrm{~N}_{y}$ [22,23], $\left(\mathrm{Zn}_{x} \mathrm{Ga}_{1-x}\right)\left(\mathrm{O}_{x} \mathrm{~N}_{1-x}\right)$ [24] are some systems that have showed very attractive results. Some perovskites, such as $\mathrm{SrTiO}_{3}: \mathrm{N}$ and $\mathrm{BaTiO}_{3}: \mathrm{N}$ [19], have also showed promising results, although the photocatalytic reaction needs to be conducted in the presence of $\mathrm{H}_{2} \mathrm{O}_{2}$ when $\mathrm{BaTiO}_{3}: \mathrm{N}$ is used. No experimental study concerning nitridation of stannates was found. However, Chen et al. [11] performed density functional theory calculations in order to evaluate the effect of cationic $\left(\mathrm{Cr}^{3+}, \mathrm{Fe}^{3+}\right.$, and $\left.\mathrm{Rh}^{3+}\right)$ and anionic $\left(\mathrm{N}^{3-}, \mathrm{N}^{2-}\right.$, and $\left.\mathrm{S}^{2-}\right)$ doping in $\mathrm{SrSnO}_{3}$ and concluded that $\mathrm{N}^{3-}$ is the most effective dopant to reduce the band gap. In this work, we discuss the nitridation of $\mathrm{SrSnO}_{3}$ as a strategy to shift its photoactivity into the visible region.

\section{Experimental procedure}

\subsection{Synthesis by solid state reaction}

The $\mathrm{SrSnO}_{3}$ was synthesized by solid state reaction. $\mathrm{SrCO}_{3}$ (Sigma-Aldrich, $99.9 \%$ purity) and $\mathrm{SnO}_{2}$ (Merck, 99.9 \% purity) powders were thoroughly mixed in an agate mortar. The mixture was initially treated at $800{ }^{\circ} \mathrm{C}$ for $6 \mathrm{~h}$ in air. After cooling, the powder was further ground, pressed in pellets and sintered at 1100 ${ }^{\circ} \mathrm{C}$ for $24 \mathrm{~h}$. After cooling, the pellets were ground again. 


\subsection{Nitridation}

$\mathrm{SrSnO}_{3}$ powder was nitrided in a horizontal tubular furnace under gas flow of $\mathrm{NH}_{3}\left(20 \mathrm{~L}^{-1} \mathrm{~h}^{-1}\right)$ varying the temperature and reaction time according to Table 1 . The heating rate was $10^{\circ} \mathrm{C} \cdot \mathrm{min}^{-1}$ and cooling was inertial. A $\mathrm{N}_{2}$ flowing was introduced during cooling $\left(20\right.$ L.h $\left.^{-1}\right)$.

Table 1. Temperature and time used in the nitridation of the $\mathrm{SrSnO}_{3}$.

\begin{tabular}{ccc}
\hline $\begin{array}{c}\text { Nitrided } \\
\text { samples }\end{array}$ & Temperature $/{ }^{\circ} \mathrm{C}$ & Time $/ \mathrm{h}$ \\
\hline B & 600 & 24 \\
C & 650 & 21 \\
D & 750 & 8 \\
\hline
\end{tabular}

\subsection{Photocatalysis tests}

The photocatalytic activity of oxide and oxynitride was investigated by means of the discolouration of an aqueous solution of methylene blue (MB) $\left(5.0 \mathrm{mg} . \mathrm{L}^{-1}\right)$. For this purpose, we used a batch type reactor containing two high pressure Hg lamps for UV tests ( $120 \mathrm{~W} ; \lambda=254 \mathrm{~nm}$ ) and two tungsten lamps (100 W) for testing in the visible. In all assays, $50.0 \mathrm{~mL}$ of $\mathrm{MB}$ solution and $25.0 \mathrm{mg}$ of catalyst were used. Every 30 minutes, aliquots $(5.0 \mathrm{~mL}$ ) were collected, the catalyst was separated by centrifugation and dye quantitation was performed by UV-Vis spectroscopy (Varian Cary 5000 UV-Vis NIR) spectroscopy, measuring the absorbance maximum at $660 \mathrm{~nm}$.

Some adsorption tests were performed in the dark under the same conditions of the photocatalytic tests. Other tests were also performed in the absence of catalyst to check photolysis of MB.

\subsection{Characterization}

All of the samples were characterized by X-ray diffraction (XRD) (Philips PW 3710 diffractometer operating with -Cuk $\alpha$ radiation of $\lambda=0.15418 \mathrm{~nm}$ for $\left.5^{\circ}-90^{\circ}(2 \theta)\right)$. The quantity of nitrogen and oxygen were measured in the synthesized powders with a TC-600 LECO ${ }^{\circledR}$ Analyzer. The specific surface area was estimated by BET isotherm (Micromeritics Flowsorb II 2300). UV-Vis spectra (Varian Cary 5000 UV-Vis NIR) were obtained by the reflectance method using $\mathrm{BaSO}_{4}$ as reference. The Kubelka-Munk function [33] was applied in order to bring the energy of the band gap. The Raman spectra were recorded with a Renishaw spectrophotometer (inVia Raman Microscope) with Ar laser source, operating at $20 \mathrm{~mW}$ and $514.5 \mathrm{~nm}$ (1 


\section{ACCEPTED MANUSCRIPT}

scan, exposure time 10000s). The images were obtained with Scanning Electron Microscope (SEM) images and Energy Dispersive Spectroscopy (EDS) analyses were performed with a JEOL - JSM 7001-F equipped with an Oxford Instruments EDS analyzer. All samples were coated with gold in order to improve conductivity.

\section{Results and discussion}

Crystalline single phase and carbonate free $\mathrm{SrSnO}_{3}$ was obtained through solid -state reaction at 1100 ${ }^{\circ} \mathrm{C}$. All of the $\mathrm{SrSnO}_{3}$ diffraction peaks were indexed according to the JCPDS 77-1798, confirming the formation of an orthorhombic perovskite structure (space group Pbnm - Fig. 1a). After the different nitridation treatments, no peak shift was observed but the perovskite structure was maintained except for the sample treated at the highest temperature $\left(750^{\circ} \mathrm{C} / 8 \mathrm{~h}\right)$, for which we observed secondary phases such as $\mathrm{SrSn}(\mathrm{OH})_{6}$ (Fig. 1d).

The Raman spectra of $\mathrm{SrSnO}_{3}$ and of nitrided samples are shown in Fig. 2. It can be seen five main bands related to the typical vibrational modes of perovskite. The main bands were assigned according to the literature [28-30]: bands at 115, 146 and $170 \mathrm{~cm}^{-1}$ correspond to the $\mathrm{Sr}_{-} \mathrm{SnO}_{3}$ network mode; the highest intensity band at $222 \mathrm{~cm}^{-1}$ is attributed to $A_{g}$ mode which corresponds to the scissors movement of the $\mathrm{Sn}-\mathrm{O}$ $\mathrm{Sn}$ group along the $\mathrm{c}$ axis. The band at $258 \mathrm{~cm}^{-1}$ is attributed to the angle variation of the $\mathrm{O}-\mathrm{Sn}-\mathrm{O}$ group at the $a b$ plan and to the scissors movement at Sn-O-Sn perpendicular to the $\mathrm{c}$ axis. Additional lower intensity bands are observed at 304, 398 e $401 \mathrm{~cm}^{-1}$ and correspond to the torsion mode of $\mathrm{SnO}_{3}{ }^{-2}$.

After nitridation, it can be observed that the bands become broader and shift to a lower frequency region indicating a local symmetry breaking and an increase of the short-range disorder. Yoon et al. [26] observed a similar effect to the $\mathrm{SrTiO}_{3}: \mathrm{N}$ system. The formation of short-range less orderly structures can be good since it is expected that $\mathrm{SnO}_{6}$ octahedra distortions favor the photocatalytic activity [31].

The surface area $\left(\mathrm{S}_{\mathrm{BET}}\right)$ was estimated by $\mathrm{N}_{2}$ adsorption isotherm (BET). As expected for powders prepared by solid state reaction, the oxide $\mathrm{SrSnO}_{3}$ precursor presented a low value of $\mathrm{S}_{\mathrm{BET}}$ (Table 2). After thermal treatment under $\mathrm{NH}_{3}$, the value of $\mathrm{S}_{\mathrm{BET}}$ increased by 4 to 5 times. The increase of the superficial area is typical of the nitridation process and more relevant to samples prepared through the solid state reaction, it means, when the precursor oxide presents low superficial area [32]. Besides the increase of the superficial area, there was a darkening of the samples indicating the loss of $\mathrm{O}$ and/or $\mathrm{N}$ inclusion $[19,27]$.

The content of $\mathrm{N}$ and $\mathrm{O}$ in the samples were measured by LECO ${ }^{\circledR} \mathrm{TC}-600$ analyzer and the $\mathrm{Sr} / \mathrm{Sn}$ atomic ratio was estimated by EDS (Table 2). It is very difficult to calculate the composition of the nitrided samples because $\mathrm{Sn}^{4+}$ reduction can occurs. Nevertheless, it is possible to observe that, considering only the content of $\mathrm{N}$ and $\mathrm{O}$, the samples would present an excess of positive charge. Thus it is necessary to imagine a charge 


\section{ACCEPTED MANUSCRIPT}

compensation mechanism. Ebbinghaus et al. [19] suggest that the charge compensation mechanism for nitrided perovskites can occur through (i) the generation of vacancy of oxygen, (ii) anionic and cationic cosubstitution, (iii) oxidation of the cation B, or (iv) reduction of the quantity of anions. EDS data show that $\mathrm{SrSnO}_{3}$ is deficient in $\mathrm{Sr}$ and this deficiency tend to be enhanced upon nitridation. Moreover, XRD data do not show the presence of any secondary phase containing reduced tin (ex. SnO or $\mathrm{Sn}^{0}$ ). Considering this, it is possible to assume that $\mathrm{Sr}^{+2}$ vacancy is a possible mechanism to charge compensation; nevertheless $\mathrm{Sn}$ reduction can not be disregarded.

Moreover, $\mathrm{LECO}^{\circledR}$ TC-600 analysis showed very low content of $\mathrm{N}$. Nonetheless, nitride samples showed a different photocatalytic behavior when compared to $\mathrm{SrSnO}_{3}$ (which will be discussed hereafter), besides enhancement in surface area and darkening. So, it is assumed that nitridation indeed occurred but it probably took place mainly at the surface of the sample. Thus, it is reasonable to suppose that there may be a region where the $\mathrm{N}$ concentration is much greater (surface) and another region where the concentration is insignificant (bulk).

Table 2. Specific Surface Area, Oxygen and Nitrogen content (\% weight) (measured by LECO ${ }^{\circledR}$ ), Optical Band Gap and Color of samples.

\begin{tabular}{|c|c|c|c|c|c|c|}
\hline Nitridation Condition & Area $/ \mathrm{m}^{2} \mathrm{~g}^{-1}$ & $0 \%$ & $\mathrm{~N} \%$ & $\begin{array}{c}\mathrm{Sr} / \mathrm{Sn} \\
\text { atomic } \\
\text { ratio }\end{array}$ & $\begin{array}{c}\text { Band } \\
\text { gap/eV }\end{array}$ & Color \\
\hline $650^{\circ} \mathrm{C} / 21 \mathrm{~h}$ & 10.0 & 17.2 & 0.114 & 0.899 & 4.0 & \\
\hline $600^{\circ} \mathrm{C} / 24 \mathrm{~h}$ & 14.7 & 18.3 & 0.065 & 0.885 & 3.9 & \\
\hline $\mathrm{SrSnO}_{3}$ & 2.8 & - & - & 0.924 & 4.0 & \\
\hline
\end{tabular}

The band gap value of the samples was estimated from analysis by means of spectroscopy at the UVVis region (Fig. 3 and Table 2). An insignificant variation on the band gap value due to the nitridation treatment was observed. On the other hand, it is noted that there is a formation of a shoulder between $2.5 \mathrm{e}$ $3.5 \mathrm{eV}$ (415 and $620 \mathrm{~nm}$, respectively) due to the treatment with $\mathrm{NH}_{3}$. This shoulder can be associated to the creation of permitted levels inside of the band gap, which can be related either to the incorporation of $\mathrm{N}$ or to the loss of reticular oxygen. These levels may come from the richer surface region in N. Yoon et al. [26] also describe the formation of a shoulder between 400 and $500 \mathrm{~nm}$ for the $\mathrm{SrTiO}_{3}: \mathrm{N}$. 


\section{ACCEPTED MANUSCRIPT}

The photocatalytic activity of the samples was evaluated through tests conducted under UV ( $254 \mathrm{~nm}$ ) and visible light, Fig. 4. The photocatalytic activity of the $\mathrm{SrSnO}_{3}$ is already known [12-15], but the commercial $\mathrm{TiO}_{2}$ (P25) was applied in similar conditions for comparison effect.

When UV radiation is used, it can be observed a small activity of the $\mathrm{SrSnO}_{3}$ and a performance about $30 \%$ superior of the nitrided samples. Nevertheless, when the visible radiation is employed, it is observed a much more intense activity for the nitride sample - approximately 4 times greater than the one observed for the $\mathrm{SrSnO}_{3}$ and 2 times greater than the one observed for the $\mathrm{TiO}_{2}$ in the same conditions. The results of the photocatalytic tests suggest that the reduction of the band gap at the surface can be considerably greater than the one evidenced at the UV-Vis spectrum (which represents an average between surface and bulk). This happens because the nitridation occurs only at the superficial region and proves that even though only subtle modifications were observed in the structure of the $\mathrm{SrSnO}_{3}$, they are efficient enough for the promotion of the photocatalytic activity at the visible region.

\section{Conclusions}

Nitridation of $\mathrm{SrSnO}_{3}$ powders was performed in different conditions. Samples of $\mathrm{SrSnO}_{3}$ submitted to nitridation in moderate conditions $\left(600-650^{\circ} \mathrm{C}\right)$ presented a significant increase in the photocatalytic activity at the visible region. The results arise from a superficial incorporation of $\mathrm{N}$, even in small proportion. In more severe conditions $\left(750^{\circ} \mathrm{C}\right)$, the nitridation leads to the degradation of the structure.

Acknowledgment: The authors would like to thank to CAPES-COFECUB (Project 644/09), INCT/CNPq/MCT and RECAM/CNPq/MCT for financial support. The Prof. F. Tessier for all support and access to laboratory facilities. The authors are grateful for the assistance in SEM observations and EDS analyses of the staff of the CMEBA facility (ScanMAT, University of Rennes 1) which received a financial support from the European Union(CPER-FEDER 2007-2014) and Laboratory Microscopy of the Institute of Sciences Biological (IB-UNB).

\section{References}

[1] J. Shi, L. Guo, Prog. Nat. Sci. 22(6) (2012) 592-615.

[2] S. Ouyang, H. Tong, N. Umezawa, J. Cao, P. Li, Y. Bi, Y. Zhang, J. Ye, J. Am. Chem. Soc. 134 (2012) 19741977.

[3] J. Shi, J. Ye, L. Ma, S. Ouyang, D. Jing, L. Guo, Chem. Eur. J. 18 (2012) 7543-7551.

[4] E.H. Mountstevens, J.P. Attfield, S.A.T.J. Redfern, Phys. Condens. Matter. 15 (2003) 8315-8326.

[5] P.H. Borse, U.A. Joshi, S.M. Ji, J.S. Jang, J. S. Lee, Appl. Phys. Lett. 90 (2007) 034103.

[6] R.L. Bucur, A.L. Bucur, F. Novaconi, I. Nicoara, J. Alloys Compd. 542 (2012) 142-146. 


\section{ACCEPTED MANUSCRIPT}

[7] A. Di Paola, E. García-López, G. Marcì, L.J. Palmisano, J. Hazard. Mater. 211-212 (2012) 3-29.

[8] M. Kocemba, A. Wróbel-Jedrzejewska, J. Szychowska, M. Rynkowski, Glówka Sens. Actuators B, 121 (2007) 401-405.

[9] J. Shi, L. Guo, Prog. Nat. Sci. Mater. Int. 22 (2012) 592-615.

[10] Y. Yuan, J. Lv, X. Jiang, Appl. Phys. Lett. 91 (2007) 094107.

[11] H. Chen, N. Umezawa, Int. J. Photoenergy 2014 (2014) 1-3.

[12] H.B. Sales, V. Bouquet, S. Députier, S. Ollivier, F. Gouttefangeas, M. Guilloux-Viry, V. Dorcet, I.T. Weber, A.G. De Souza, I.M. Dos Santos, Solid State Sci. 28 (2014) 67-73.

[13] D. Chen, J.H. Ye, Chem. Mater. 19 (2007) 4585-4591.

[14] C.W. Lee, D.W. Kim, I.S. Cho, S. Park, S.S. Shin, S.W. Seo, K.S. Hong, Int. J. Hydrogen Energy 37 (2012) 10557-10563.

[15] P. Junploy, S. Thongtem, T. Thongtem, Superlattices Microstruct. 57 (2013) 1-10.

[16] R. Asahi, T. Morikawa, T. Ohwaki, K. Aoki, Y. Taga, Science 293 (2001) 269-271.

[17] W.F. Zhang, J.W. Tang, J.H. Ye, Chem. Phys. Lett. 418 (2005) 174-178.

[18] V. Kumar, G.S. Uma, J. Hazard. Mater. 189 (2011) 502-508.

[19] S.G. Ebbinghaus, Abicht, Hans-Peter, R. Dronskowski, T. Müller, A. Reller, A. Weidenkaff, J. Solid State Chem. 37 (2009) 173-205.

[20] M.R. Hoffmann, S.T. Martin, W. Choi, D.W. Bahnemann, Chem. Rev. 95 (1995) 69-96.

[21] Z. Guo, B. Sa, B. Pathak, J. Zhou, R. Ahuja, Z. Sun, J. Hydrogen Energy, 39 (2014) 2042-2048.

[22] J.H. Hsieh, C. Li, H.C. Liang, Thin Solid Films 519 (2011) 4699-4704.

[23] M.Y. Tsang, N.E. Pridmore, L.J. Gillie, Y.H. Chou, R. Brydson, Adv. Mat. 24 (2012) 3406-3209.

[24] M. Yashima, H. Yamada, K. Maeda, K. Domen, Chem. Comm. 46 (2010) 2379-2381.

[25] X. Chen, Y. Lou, A.C.S. Sarnia, C. Burda, J.L. Gole, Adv. Funct. Mater. 15 (2005) 41-49.

[26] S. Yoon, A.E. Maegli, L. Karvonen, S.K. Matam, A. Shkabko, S. Riegg, J. Solid State Chem. 206 (2013) 226232.

[27] I.T. Weber, N. Audebrand, V. Bouquet, M. Guilloux-Viry, A. Perrin, Solid State Sci. 8 (2006) 606-612.

[28] G.L. Lucena, I.M.G. Santos, J.J.N. Souza, A.S. Maia, L.E.B. Soledade, E. Longo, A.G. Souza, Cerâmica 59 (2013) 249-253.

[29] J.M. Moreira, D.L. Henriques, E.W.S. Azevedo, V.N. Caetano, E.L. Freire, Albuquerque, J. Solid State Chem. 187 (2012) 186-194.

[30] M.C.F. Alves, R.M.M. Marinho, G.P. Casali, M. Siu-Li, S. Députier, M. Guilloux-Viry, A.G. Souza, E. Longo, I.T. Weber, I.M.G. Santos, V. Bouquet, J. Solid State Chem. 199 (2013) 34-41. 


\section{ACCEPTED MANUSCRIPT}

[31] W.F. Zhang, J.W. Tang, J.H. Ye, Chem. Phys. Lett. 418 (2006) 174.

[32] J.F. Figueiredo, V. Bouquet, S. Députier, O. Merdrignac-Conanec, I. Peron, E.P. Marinho, A.G. Souza, M. Guilloux-Viry, I.T. Weber, Cerâmica 59 (2013) 269-276.

[33] S. P. Tandon and J. P. Gupta, Phys. Status Solidi 38, 363-367 (1970). 


\section{Figure}

Fig. 1. X-ray diffraction patterns of a) $\mathrm{SrSnO}_{3}$; b) $\mathrm{SrSnO}_{3}$ treated under $\mathrm{NH}_{3}$ flow at $600{ }^{\circ} \mathrm{C} / 24 \mathrm{~h}$; c) $\mathrm{SrSnO}_{3}$ treated under $\mathrm{NH}_{3}$ flow at $650{ }^{\circ} \mathrm{C} / 21 \mathrm{~h}$ and d) $\mathrm{SrSnO}_{3}$ treated under $\mathrm{NH}_{3}$ flow at $750{ }^{\circ} \mathrm{C} / 8 \mathrm{~h}$. Magnification of X-ray diffraction peaks evidencing peak shift and broadening as function of nitridation treatment.

Fig. 2. Raman spectra of a) $\mathrm{SrSnO}_{3}$; b) $\mathrm{SrSnO}_{3}$ treated under $\mathrm{NH}_{3}$ flow at $600{ }^{\circ} \mathrm{C} / 24 \mathrm{~h}$ and c) $\mathrm{SrSnO}_{3}$ treated under $\mathrm{NH}_{3}$ flow at 650 ${ }^{\circ} \mathrm{C} / 21 \mathrm{~h}$.

Fig. 3. UV-visible spectra of a) $\mathrm{SrSnO}_{3}$; b) $\mathrm{SrSnO}_{3}$ treated under $\mathrm{NH}_{3}$ flow at $600{ }^{\circ} \mathrm{C} / 24 \mathrm{~h}$; and c) $\mathrm{SrSnO}$ treated under $\mathrm{NH}_{3}$ flow at $650{ }^{\circ} \mathrm{C} / 21 \mathrm{~h}$.

Fig. 4. Discoloration of $\mathrm{MB}$ dye upon (A) UV and (B) visible light: a) $\mathrm{SrSnO}_{3}$; b) $\mathrm{SrSnO}_{3}$ treated under $\mathrm{NH}_{3}$ flow at $600{ }^{\circ} \mathrm{C} / 24 \mathrm{~h}$; c) $\mathrm{SrSnO}_{3}$ treated under $\mathrm{NH}_{3}$ flow at $650{ }^{\circ} \mathrm{C} / 21 \mathrm{~h}$; and d) $\mathrm{TiO}_{2}$. 


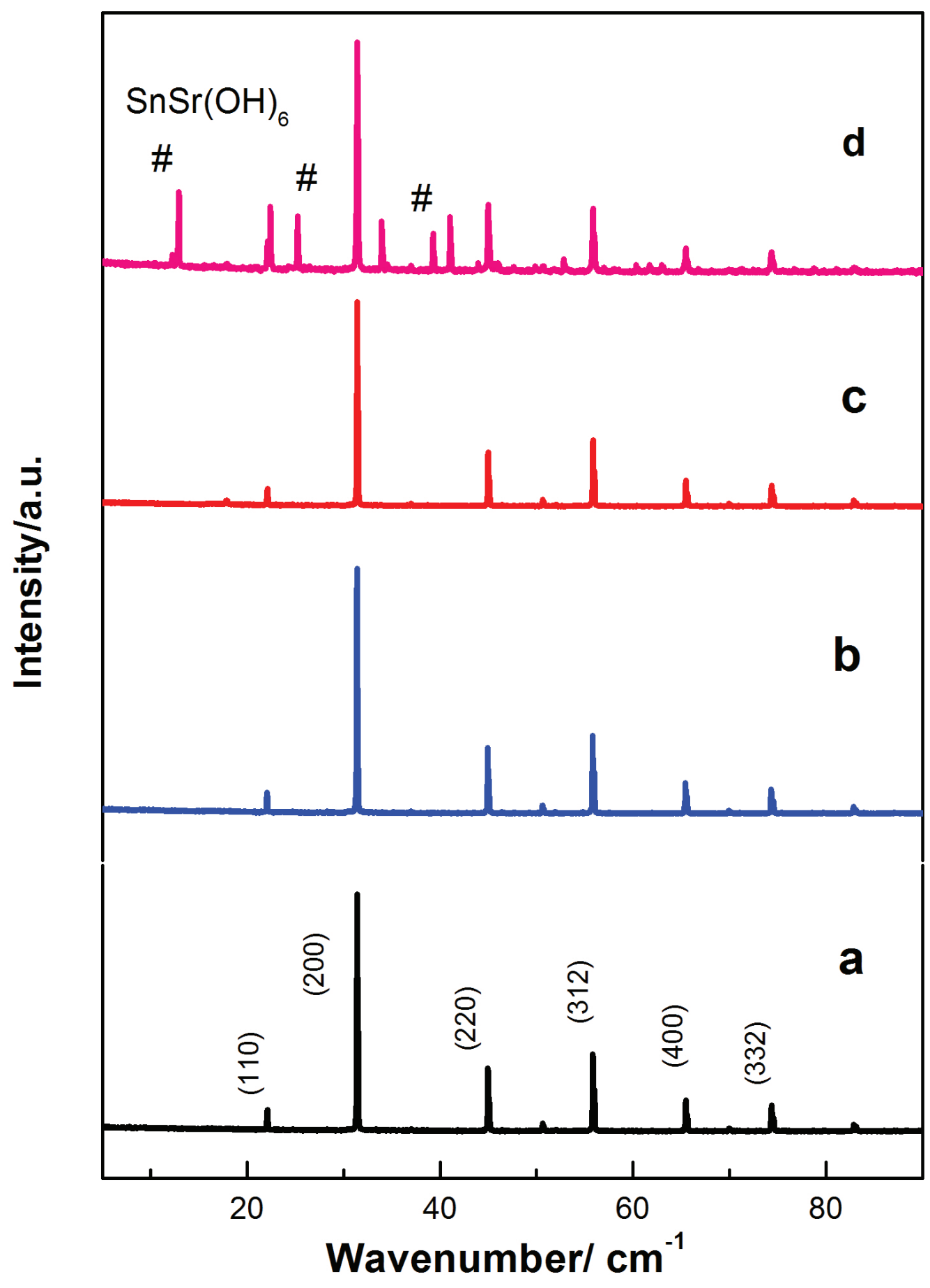




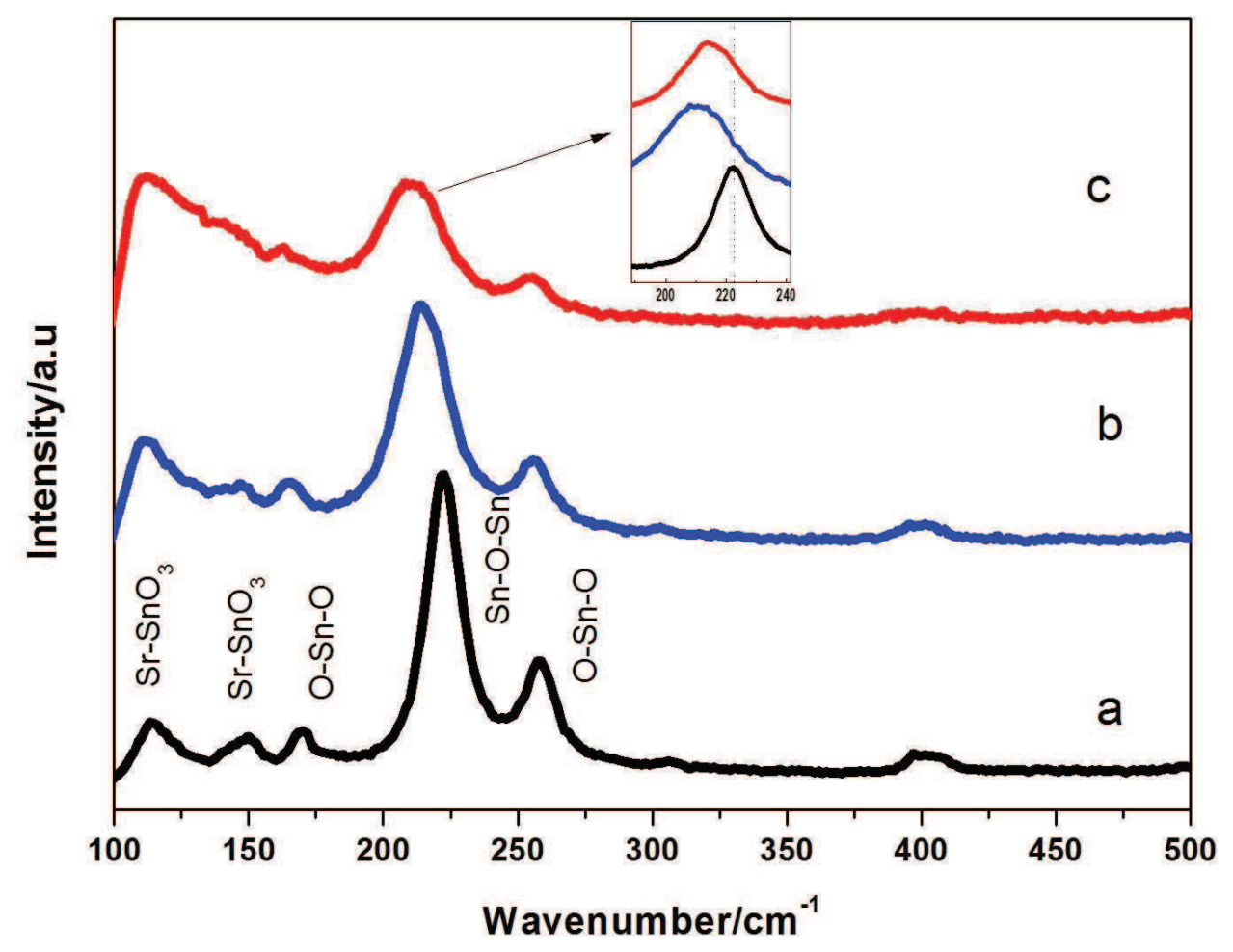




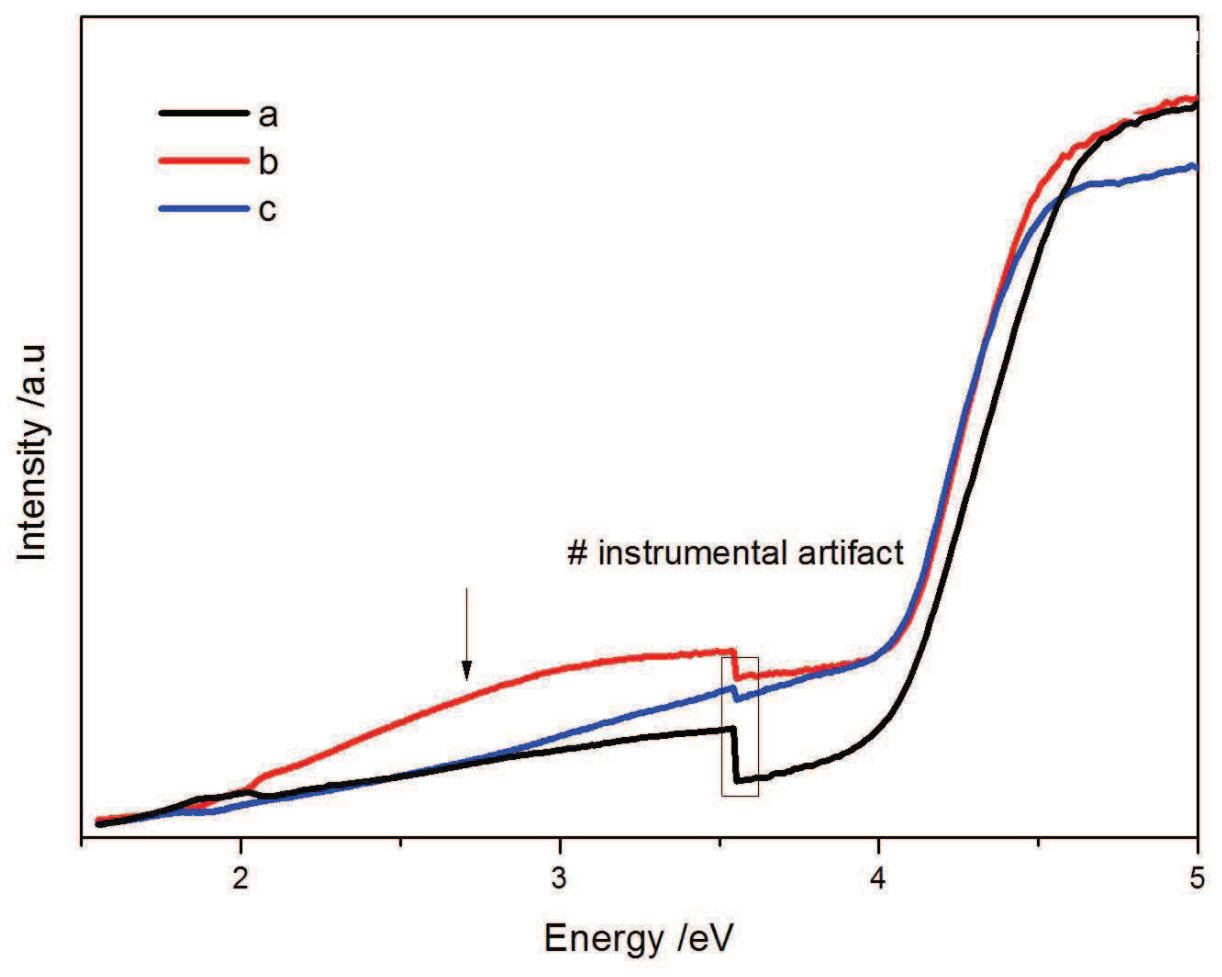



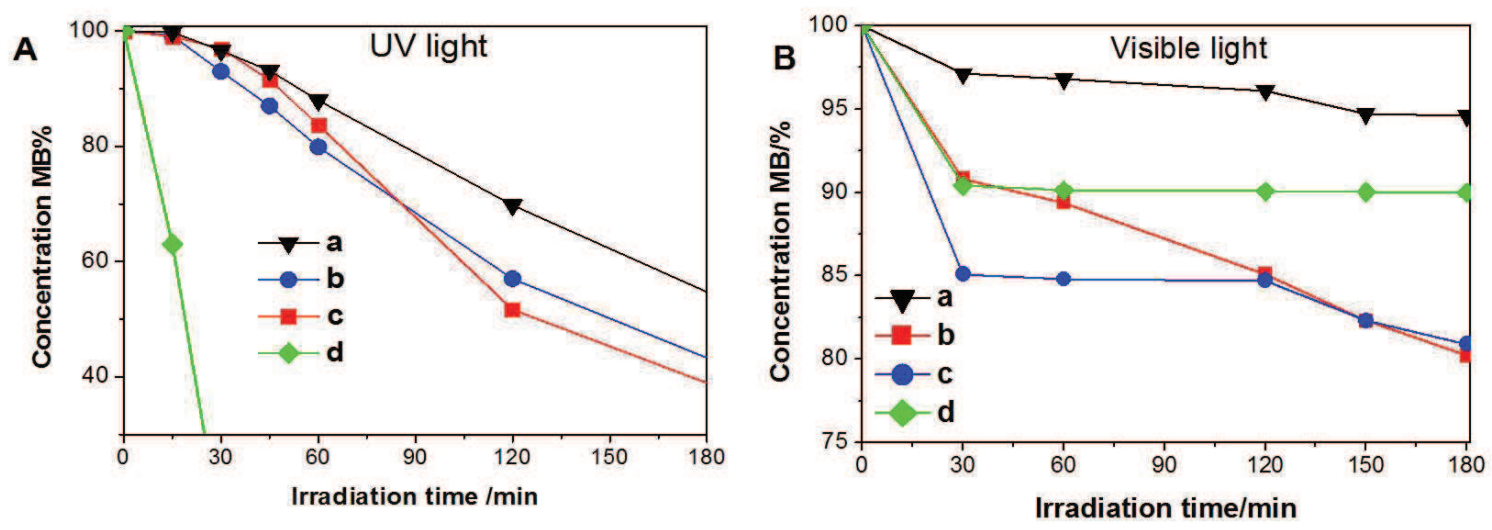


\section{$\mathrm{SrSnO}_{3}: \mathrm{N}-$ nitridation and evaluation of photocatalytic activity}

\section{Highlights}

- $\mathrm{SrSnO}_{3}: \mathrm{N}$ presents a great potential to be used as photocatalyst under visible light.

- Very low amount of $\mathrm{N}$ increase significantly the photoactivity of $\mathrm{SrSnO}_{3}: \mathrm{N}$ under visible light.

- Nitridation of $\mathrm{SrSnO}_{3}$ was succeed at mild conditions and the peroviskite structure was preserved. 